\title{
SLOPE STABILITY ANALYSIS FOR EARTH DAMS USING (GEO-SLOPE/W)
}

\author{
Jasim M Abbas ${ }^{1}$, Zainab Ali Mutiny' ${ }^{2}$ \\ ${ }^{1}$ Assistant Professor, ${ }^{2}$ M. Sc. Student, Department of Civil Engineering, Engineering College, \\ University of Diyala \\ jasimalshamary@yahoo.com
}

\begin{abstract}
The study of slope stability is important in the design and construction of the earth dams under influence of special states. Some factors affect on the slope stability for the earth dams such as change the water level in the reservoir, dam configuration, material properties..etc. In this study, the factor of safety of upstream slope stability for number of exist earth dams has been assessed. To achieve the objective of this study, Geo-SLOPE/W program that based on limit equilibrium methods was used. Taking into account the case of dry condition and gradually rise of water level in upstream part for these dams. It can be seems that the slope stability of the earth dams increased in case of dry condition. In addition, the slope stability increased when the water reach to maximum value.
\end{abstract}

Keywords: Earth Dams, Slope Stability, GeoSLOPE/W.

Paper History: Received February 2, 2011, Accepted October 5, 2011

\section{Introduction}

One of the important stages in design of earth dam is the evaluation slope stability for upstream slope for earth dams. Number of previous studies takes into account the influence of many factors on the $(F)$. Pham et al., 2013 studied the effect of the water levels on the upstream slope of the earth dam (Yashigou in Chine), were considered without water level and steady state water level and drawdown of the water level in the reservoir using Geo-studio software SLOPE/W and SEEP/W programs, to analysis "factor of safety" for the stability of slope for earth dam used (Morgenstern-Price and finite element stress)methods. Kubba and Aqeel, 2013 studied the slope stability of earth dam which is located in north of Iraq. The analysis stability for upstream and downstream slopes by using hand calculation (Bishop) method and (SLOPEBG) program for the purpose comparison the results. Abhilasha and Ashwini, 2014 calculated the values of factor of safety for downstream slope of (Poomala) dam in India for variable pore water pressure condition based on (Ordinary, Bishop, Janbu, Morgenstern-Spencer) methods, using (Geostudio) software(SLOPE/W) program to find the factor of safety for the earth dam. Athani, et al., 2015founded the values of factor of safety for upstream slope for the earth dam and seepage analyses by using finite element method (PLAXIS 3D software) of the earth dam is located in India. The seepage analysis is divided into two steps, steady state and transient analyses. The slope stability for upstream slope of the earth dam has been studied for the following conditions: (a) full (high) reservoir level of the earth dam, (b) rapid drawdown in 5 and 10 days duration, (c) slow drawdown in 50 days duration and (d)low water level of the earth dam.

Andreea, 2015study the slope stability of (Maneciu) earth dam with a 78 meter high and $200 \mathrm{~m}$ width, in Romania. The analysis including three stages which are: (a) the first stage is steady state analysis (full reservoir) with water level at $74 \mathrm{~m}$ height, (b) the second stage is drawdown of water level to $50 \mathrm{~m}$ (transient analysis with time) and (c) the third stage is after maintaining the water level $50 \mathrm{~m}$ for a long time. This study used Strength Reduction Method (3D) program to calculate the values of the "factor of safety" for upstream slope for the earth dam.

Therefore, the paper presents the results of LEM of the stability analyses of the earth dam using Geo-SLOPE/W software taking into account the factors that affected on the slope stability performance.

\section{2- STUDIED CASES}

The following cases was taken in this analysis:

A-Wand dam: The dam is located in Diyala-Iraq. Wand dam which analysis in software program use without paving of the layer materials to prevent water leakage inside the earth dam. The cross-section of Wand dam is shown in Figure(1).(Ministry of water resources in Iraq, 2011), with soil properties of $\left(c=0, \phi=39^{\circ}, \gamma=21 \mathrm{kN} / \mathrm{m}^{3}\right)$

B-Horan dam H-2 is an earth dam located $18 \mathrm{Km}$ north east of Al- Rutba in Iraq. The 
cross-section of Horan dam $\mathrm{H}-2$ is shown in Figure(2). (Abdul Kareem, 2010), with soil properties of $\left(c=10 \mathrm{kN} / \mathrm{m}^{2}, \phi=32^{\circ}, \gamma=21 \mathrm{kN} / \mathrm{m}^{3}\right)$

C-Nian dam(1) is an earth dam is located in Hormozgan in Iran. The cross-section of Nian dam is shown in Figure(3). (Soleimani and Adel, 2014), with soil properties of $(c=0$, $\left.\phi=43^{\circ}, \gamma=23 \mathrm{kN} / \mathrm{m}^{3}\right)$ and $(\mathrm{H}=27.3 \mathrm{~m})$

D-Nian dam(2) is an earth dam is located in south of Iran. The cross-section of Nian dam is shown in Figure(4). (Bagheri, 2006), with soil properties of $\left(c=0, \quad \phi=43^{\circ}, \quad \gamma=23 \mathrm{kN} / \mathrm{m}^{3}\right)$ and $(\mathrm{H}=32 \mathrm{~m})$

E-Poomala damis located at Kerala in India. The cross-section of Poomala damis shown in Figure(5).(Abhilasha and Ashwini, $2014)$, with soil properties of $\left(c=29 \mathrm{kN} / \mathrm{m}^{2}\right.$, $\left.\phi=18^{\circ} \gamma=16 \mathrm{kN} / \mathrm{m}^{3}\right)$.

\section{3- METHOD OF ANALYSIS}

Limit equilibrium methods are important in slopes stability analyses. These methods calculation the "factor of safety" $(F)$ by dividing a potential sliding mass into several vertical slices. All these methods used based on certain assumptions for the inter slice normal $(E)$ and shear $(T)$ forces. This assumption is a main part in distinction between limit equilibrium method from another and the basic difference among the methods is how these forces are determined or assumed. In addition to this the shape of the assumed slip surface and the forces directions that acting on each slice in the slope are assumed. The ordinary method (1936) was developed this method and is sometimes referred to as "Fellenius method". The Ordinary method satisfies the moment equilibrium for a circular slip surface, but neglects both the inter slice normal and "shear forces". The advantage of this method is its simplicity in solving the $(F)$. Abramson et al. and Nash (as cited in Aryal, 2006). Bishop simplified method (1955) advanced, this method is very common in practice for circular shear surface (SS). This method considers the inter slice normal forces but neglects the inter slice shear forces (Michael, 2003). Janbu's simplified method this method which is based on a composite shear surface (i.e. non-circular) and the $\left(F_{f}\right)$ is determined by horizontal force equilibrium, as in (Bishop simplified method), and this method does not satisfy moment equilibrium and considers inter slice normal forces $(E)$ but neglects the shear forces $(T)$. Janbu (as cited in Aryal, 2006). Spencer's method this method is the same (Morgenstern-Price)method except the assumption made for inter slice forces, the forces considered in this method. Spencer (as cited in Aryal, 2006). Morgenstern-Price method, this method satisfies both force and moment equilibriums and assumes the inter slice force function. According to method Morgenstern-Price (as cited in Rashed, 2014).

\section{4-RESULTS AND DISCUSSION}

In this study the factor of safety calculate for upstream slope of earth dams using (Morgenstern-price(M1),Spencer(M2),

Bishop(M3), Janbu (M4), Ordinary(M5)). In the cases: a- at the end of construction (dry condition) and 2- gradually rise of the water level (h) for the reservoir. The minimum values of $(F)$ for all cases are detailed in Tables $(1,2$, $3,4,5)$. In addition the shape of the critical slip surfaces of the upstream slope for the earth dams is analyzed using circular failure surface are shown in Figures $(6,7,8,9,10)$.

The relationship between the minimum $(F)$ and water level $(\mathrm{m})$ is shown in Figure (11). It can be seen that the values of $(F)$ are decreased between $(\mathrm{h}=0$ to $9.6 \mathrm{~m})$ because used the value of soil cohesion equal 0 . This leads to increasing the pore water pressure inside the dam body, as a result of that the resisting force decrease, which role decrease the values of factor of safety. While the values of factor of safety becomes increase when the water level (h) greater than $(9.6 \mathrm{~m})$ due to increase the water forces supported the upstream slope face that decreasing the driving forces.

It can be seen from the Figure (12) that the values of $(F)$ decreases between $(\mathrm{h}=0$ to $2.8 \mathrm{~m})$ because of increasing the pore water pressure inside the dam body, as a result of that the resisting force decrease, which role decrease the values of factor of safety. While the values of factor of safety becomes increase when the water level(h) greater than $(2.8 \mathrm{~m})$ because increase the water forces supported the upstream slope face that decreasing the driving forces.

It can be noted from the Figure (13) that the values of $(F)$ decreases between $(\mathrm{h}=0$ to $5.46 \mathrm{~m}$ ) due to use the value of (cohesion equal 0 )which leads to increasing the pore water pressure inside the dam body, as a result of that the resisting force decreases, which role decrease the values of factor of safety. While the values of factor of safety becomes increase when the water level(h) greater than $(5.46 \mathrm{~m})$ because of increasing the water forces supported the upstream slope face that decreasing the driving forces.

The relationship between the minimum $(F)$ and water level(m) as shown in Figure (14). It can be seen from the Figure that the values of factor of safety are decreased between $(h=0$ to 
$6.4 \mathrm{~m}$ ) due to use the value of (cohesion equal 0 )which leads to increasing the pore water pressure inside the dam body, as a result of that the resisting force decrease, which will decrease the values of factor of safety. While the values of factor of safety becomes increase when the water level(h) greater than $(6.4 \mathrm{~m})$ because of increasing the water forces supported the upstream slope face that decreases the driving forces.

The relationship between the minimum $(F)$ and water level(m) for poomala dam is shown in Figure (15). It could be seen from the Figure that the values of factor of safety decrease between ( $\mathrm{h}=0$ to $3.8 \mathrm{~m}$ ) because of increasing the pore water pressure inside the dam body, as a result of that the resisting force decreases, which role decrease the values of factor of safety. While the values of factor of safety become increase when the water level(h) greater than $(3.8 \mathrm{~m})$ because of increasingmthe water forces supported the upstream slope face that decreasing the driving forces.

The values of factor of safety $(F)$ that calculated by (Morgenstern-Price method (M1), Spencer's method (M2), Bishop simplified method (M3), Janbu's simplified method (M4), Ordinary method (M5)) with small differences can be observed. The differences between all values of factor of safety which passed previously agree with what Duncan (as cited in Griffiths and Lane,1999) which refers that "The differences between the values of the safety factor obtained with the various methods are generally lower than 6\%".

\section{5- CONCLUSIONS}

The results of this study the following conclusion could be placed:

Generally, that the slope stability of the earth dams increases when the dams body are dry while the slope stability of upstream slope for Wand dam, Nian dam(1) and Nian dam(2) is less than the slope stability for Horan dam H-2 and Poomala dam, because of the appropriate heights to Horan dam $\mathrm{H}-2$ and Poomala dam. For Wand dam, Nian dam(1) and Nian $\operatorname{dam}(2)$ it can be noted that the values of factor of safety, are decreased between (dry condition to medium value), because used the value of (cohesion equal 0) which leads to increasing the pore water pressure inside the dam body and the values of factor of safety become increase when the water level greater than (medium value) because increase the water forces supported the upstream slope face. In addition that the values of factor of safety $(F)$ calculated by (Morgenstern-Price method (M1), Spencer's method (M2), Bishop simplified method (M3), Janbu's simplified method (M4), Ordinary method (M5)), have insignificant differences for all methods.

\section{6- REFERENCES}

1. Pham, H. T.,Htet, Z., Cheng, J.,(2013),Stability of Slope and Seepage Analysis in Earth Dam Using Numerical Finite Element Model, Study of Civil Engineering and Architecture (SCEA),2(4), 104-108.

2. Kubba, F.A. and Aqeel R. L.,(2013), Assessment of Earth Dams Slope Stability By Computer Software, Australian Journal of Basic and Applied Sciences, 7(6),229-236.

3. Ministry of water resources in Iraq,(2011), Encyclopedia of dams in Iraq,132.

4. Aryal, K. P.,(2006),Slope Stability Evaluations by Limit Equilibrium and Finite Element Methods. Ph.D. Thesis, University of Science and Technology, Norwegian.

5. Michael, J. W.,(2003),Engineering and Design Slope Stability. U. S. Army Corps of Engineers, EM 1110-2-1902,(1-2), (c-8),(c14),(3-2),(3-4).

6. Rashed D. A.,(2014),A New Prediction Model for Slope Stability Analysis. DICAM.SettoreConcorsuale di afferenza: 08/B1 Geotecnica, 1-98.

7. Abdul Kareem, A.H., (2010), Analysis of the construction behavior of western desert Horan dam H-2, Journal of Iraqi Desert Studies, 2(2), 60 .

8. Bagheri, H., (2006), Application of jet grouting for water tightening of coarse grained alluvium, Dams and Reservoirs, Societies and Environment in the $21^{\text {st }}$ century, 647.

9. Abhilasha, P. S. and Ashwini, S., (2014), Stability Analysis of an Embankment Dampoomala Dam Case Study, International Journal for Scientific Research \& Development, 2(10),428-431.

10. Griffiths, D.V. and P.A. Lane,(1999),Slope Stability Analysis by Finite elements, Geotechnique, 49(3),387-403.

11. Athani, S. S.,Shivamanth, C. H., Solanki and G. R. D.,(2015),Seepage and Stability Analyses of Earth Dam Using Finite Element Method, International Conference on Water Resources, Coastal and Ocean Engineering,876 - 883.

12. Andreea, C., (2015),Unsaturated Slope Stability and Seepage Analysis of a Dam, Sustainable Solutions for Energy and Environment, Eenviro, 18-20 November,93-98.

13. Soleimani ,S. and A. Asakereh,(2014), Evaluation of static stability of earth dams using geo-studio software. International Journal of Engineering, Fascicule, 3:265-268. 
Table (1) minimum values of (F)for gradually rise (h)for Wand dam

\begin{tabular}{|c|c|c|c|c|c|}
\hline $\begin{array}{c}\text { Water } \\
\text { level(m) }\end{array}$ & M1 & M2 & M3 & M4 & M5 \\
\hline $0($ dry $)$ & 2.029 & 2.028 & 2.03 & 2.027 & 2.027 \\
\hline 4.8 & 2.014 & 2.014 & 2.016 & 1.96 & 1.949 \\
\hline 9.6 & 1.977 & 1.976 & 1.974 & 1.918 & 1.901 \\
\hline 14.4 & 2.009 & 2.008 & 2.012 & 1.962 & 1.982 \\
\hline 19.2 & 2.025 & 2.029 & 2.03 & 2.027 & 2.061 \\
\hline
\end{tabular}

Table (2) minimum values of $(F)$ for gradually rise (h) for Horan dam $\mathrm{H}-2$

\begin{tabular}{|c|c|c|c|c|c|}
\hline $\begin{array}{c}\text { Water } \\
\text { level(m) }\end{array}$ & M1 & M2 & M3 & M4 & M5 \\
\hline $0($ dry $)$ & 2.55 & 2.55 & 2.55 & 2.473 & 2.484 \\
\hline 2.8 & 2.426 & 2.427 & 2.427 & 2.358 & 2.366 \\
\hline 5.6 & 2.442 & 2.442 & 2.441 & 2.367 & 2.375 \\
\hline 8.4 & 2.617 & 2.617 & 2.617 & 2.528 & 2.557 \\
\hline 11.2 & 2.876 & 2.876 & 2.872 & 2.781 & 2.881 \\
\hline
\end{tabular}

Table (3) minimum values of (F)for gradually rise (h)for Nian dam(1)

\begin{tabular}{|c|c|c|c|c|c|}
\hline $\begin{array}{c}\text { Water } \\
\text { level(m) }\end{array}$ & M1 & M2 & M3 & M4 & M5 \\
\hline $0($ dry $)$ & 1.834 & 1.834 & 1.834 & 1.721 & 1.678 \\
\hline 5.46 & 1.677 & 1.682 & 1.71 & 1.518 & 1.469 \\
\hline 10.92 & 1.733 & 1.739 & 1.768 & 1.555 & 1.469 \\
\hline 16.38 & 1.819 & 1.82 & 1.819 & 1.631 & 1.534 \\
\hline 21.84 & 1.827 & 1.827 & 1.827 & 1.704 & 1.629 \\
\hline
\end{tabular}

Table (4) minimum values of (F)for gradually rise (h)for Nian dam(2)

\begin{tabular}{|c|c|c|c|c|c|}
\hline $\begin{array}{c}\text { Water } \\
\text { level(m) }\end{array}$ & M1 & M2 & M3 & M4 & M5 \\
\hline 0 (dry) & 1.705 & 1.713 & 1.761 & 1.556 & 1.536 \\
\hline 6.4 & 1.564 & 1.573 & 1.607 & 1.414 & 1.348 \\
\hline 12.8 & 1.58 & 1.59 & 1.628 & 1.434 & 1.34 \\
\hline 19.2 & 1.64 & 1.65 & 1.695 & 1.49 & 1.394 \\
\hline 25.6 & 1.712 & 1.722 & 1.767 & 1.567 & 1.482 \\
\hline
\end{tabular}

Table (5) minimum values of $(F)$ for gradually rise (h)for Poomala dam

\begin{tabular}{|c|c|c|c|c|c|}
\hline $\begin{array}{c}\text { Water } \\
\text { level(m) }\end{array}$ & M1 & M2 & M3 & M4 & M5 \\
\hline $0($ dry) & 1.371 & 1.371 & 1.367 & 1.354 & 1.353 \\
\hline 3.8 & 1.37 & 1.37 & 1.365 & 1.352 & 1.351 \\
\hline 7.6 & 1.375 & 1.376 & 1.369 & 1.357 & 1.357 \\
\hline 11.4 & 1.499 & 1.501 & 1.501 & 1.462 & 1.463 \\
\hline 15.2 & 1.875 & 1.873 & 1.878 & 1.819 & 1.811 \\
\hline
\end{tabular}




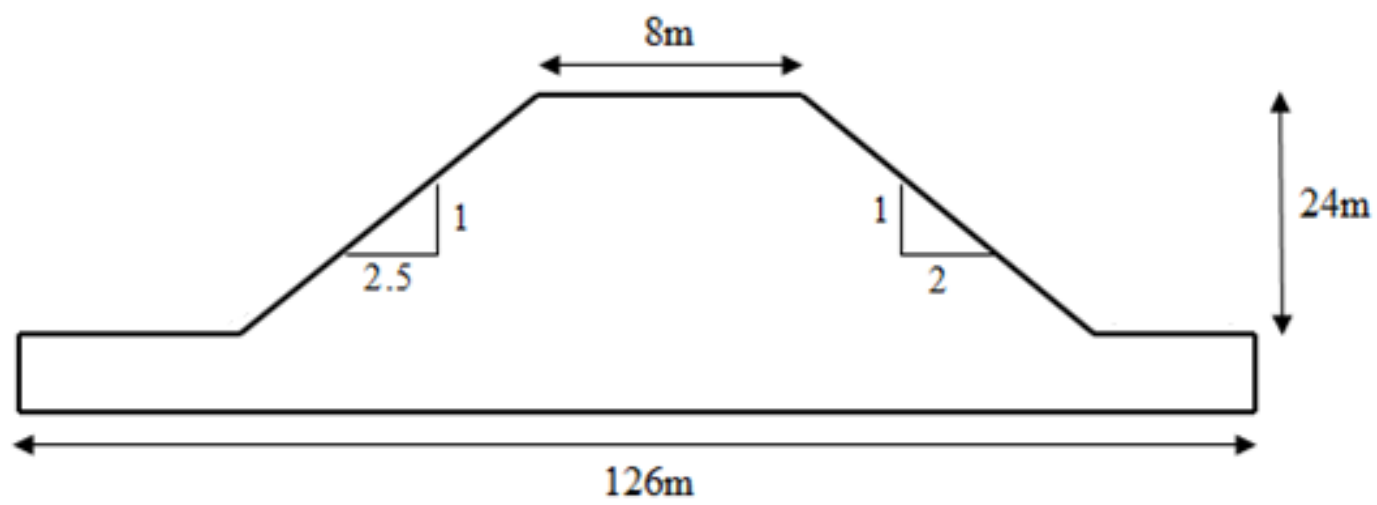

Figure (1): Cross-section of Wand dam

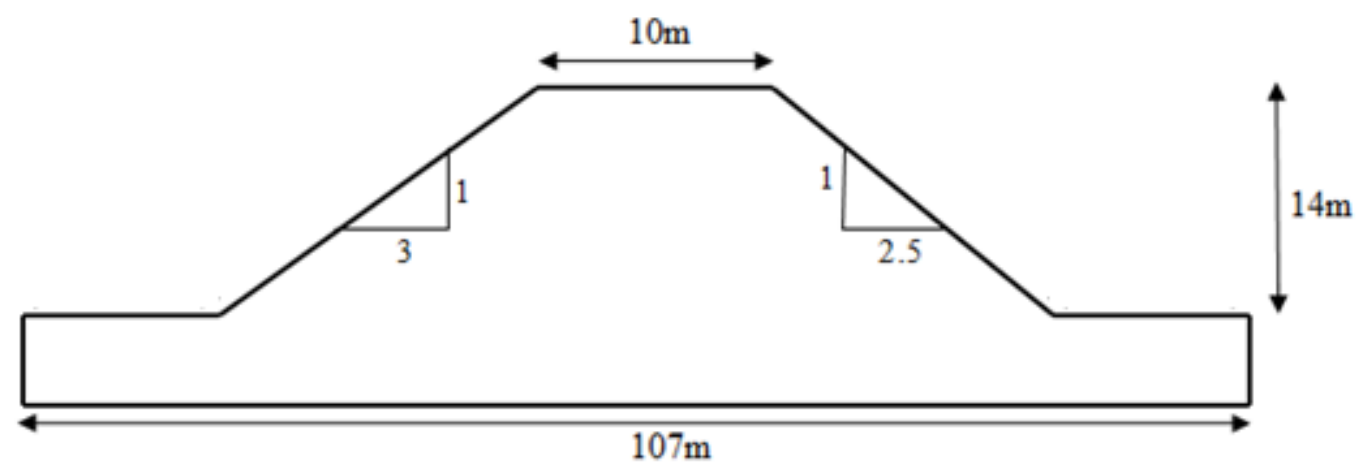

Figure (2): Cross-section of Horan dam H-2

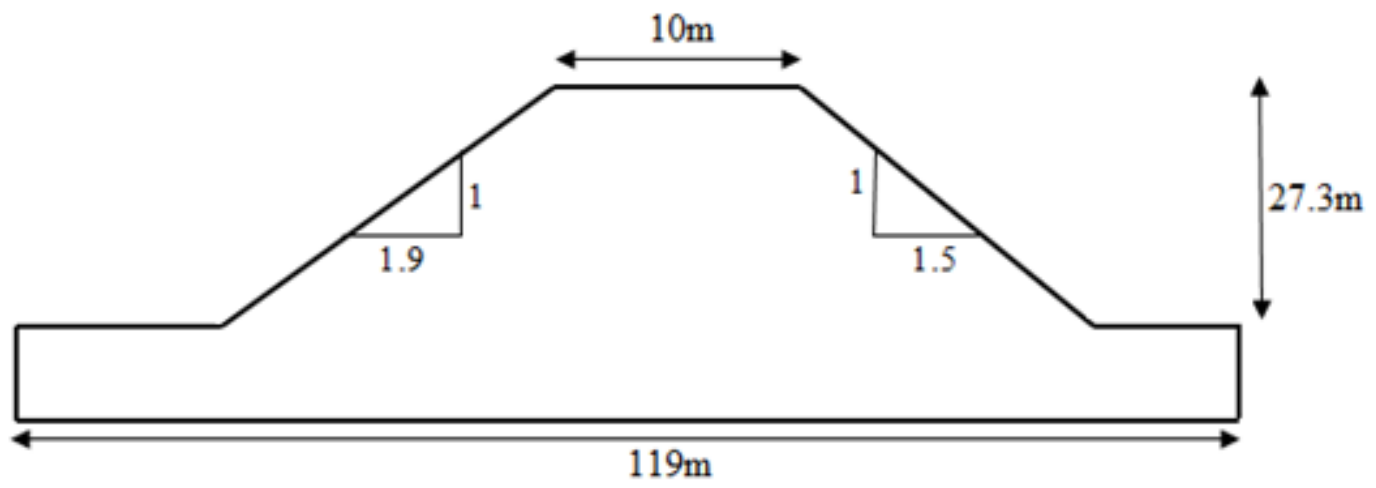

Figure (3): Cross-section of Nian dam(1)

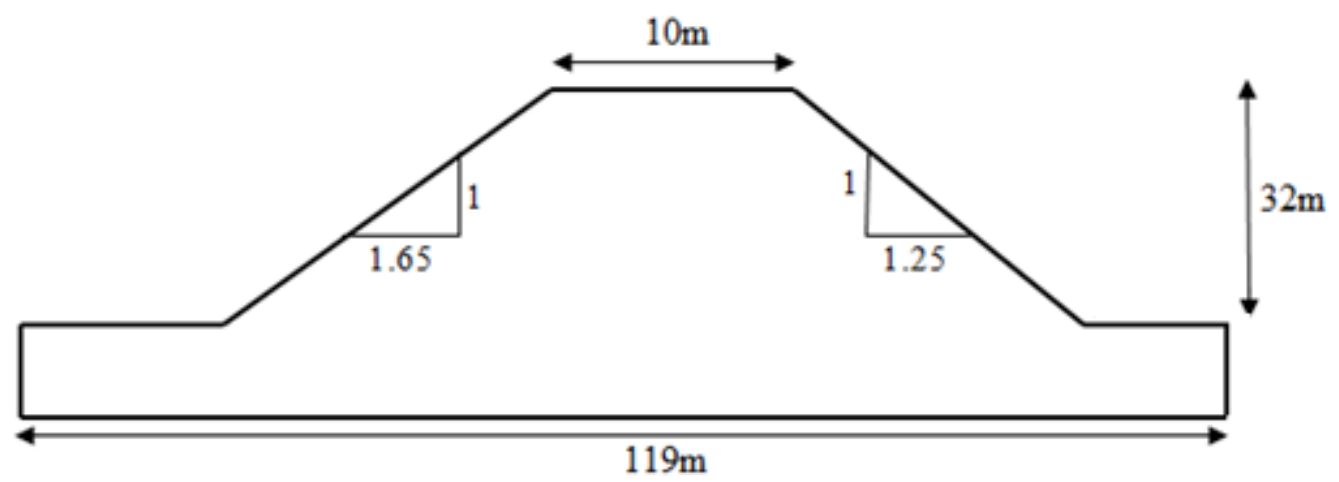

Figure (4): Cross-section of Nian dam(2) 


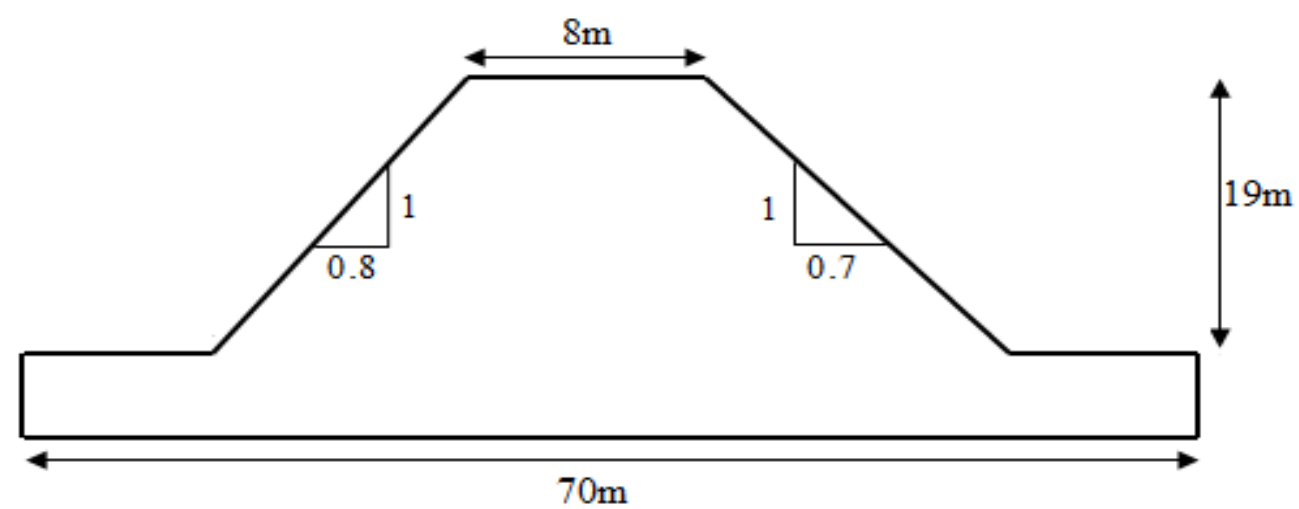

Figure (5): Cross-section of Poomala dam

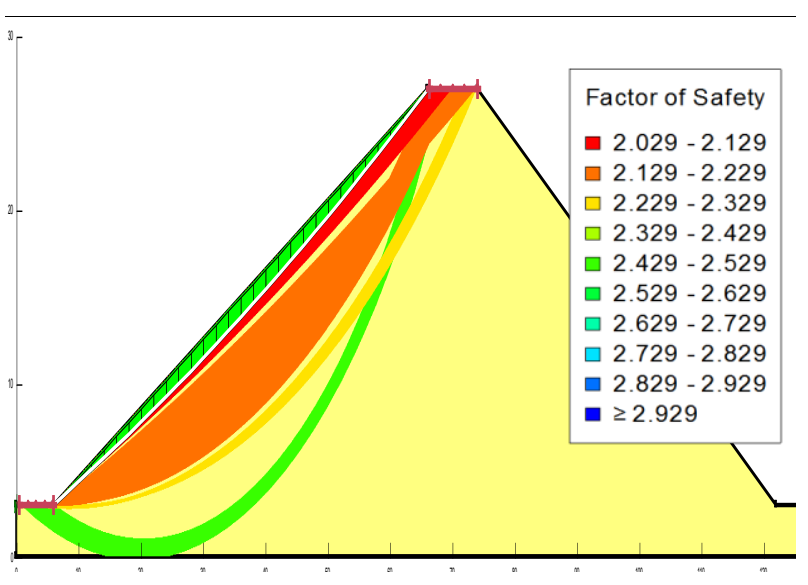

(a) $\mathrm{h}=0$

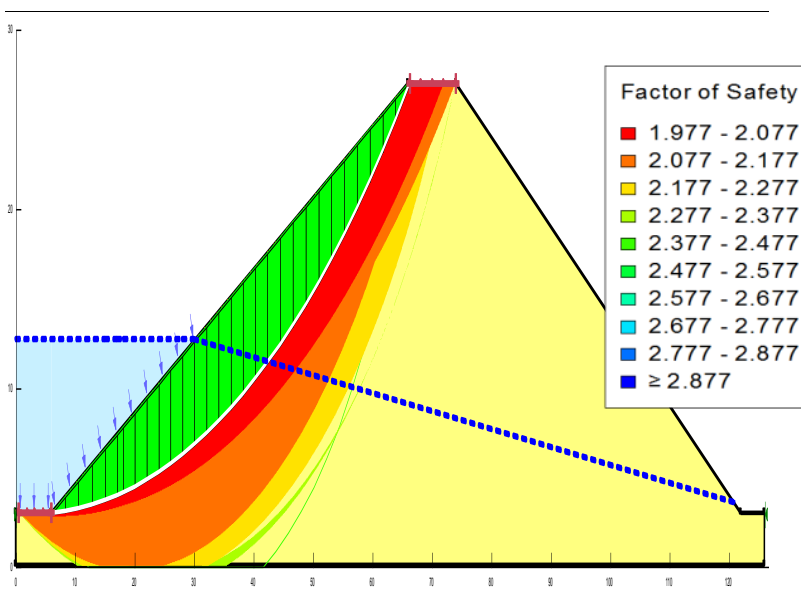

(c) $\mathrm{h}=0.4 \mathrm{H}$

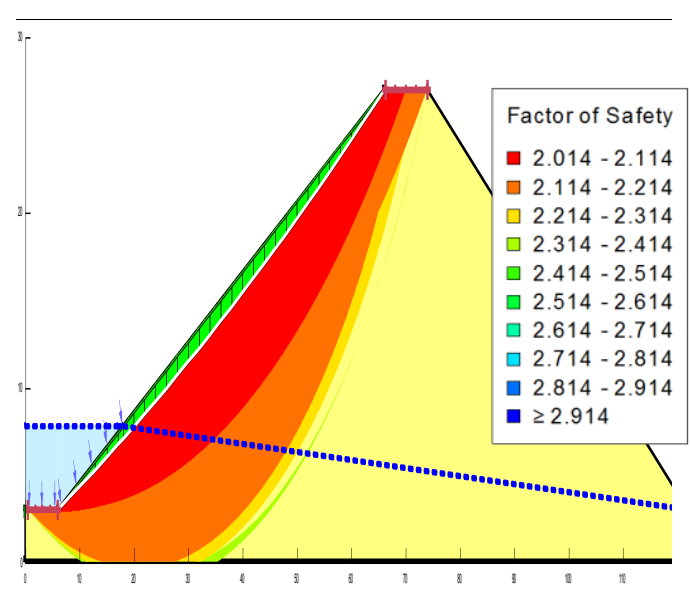

(b) $\mathrm{h}=0.2 \mathrm{H}$

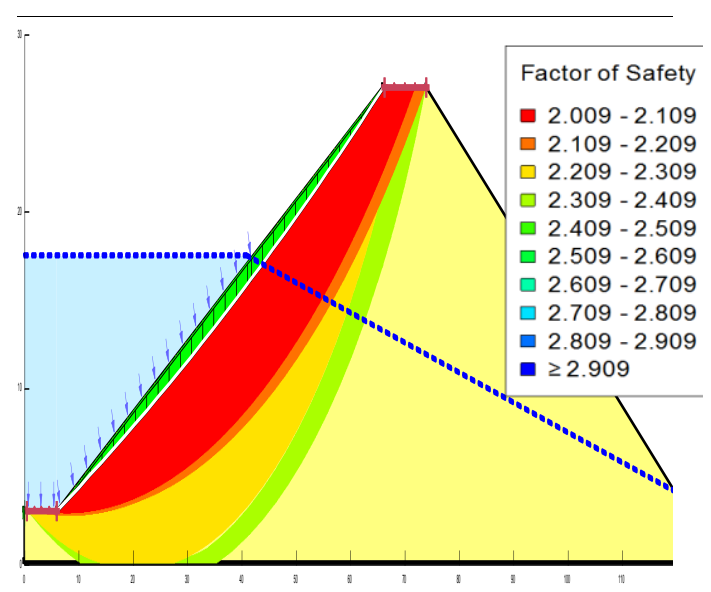

(d) $\mathrm{h}=0.6 \mathrm{H}$ 


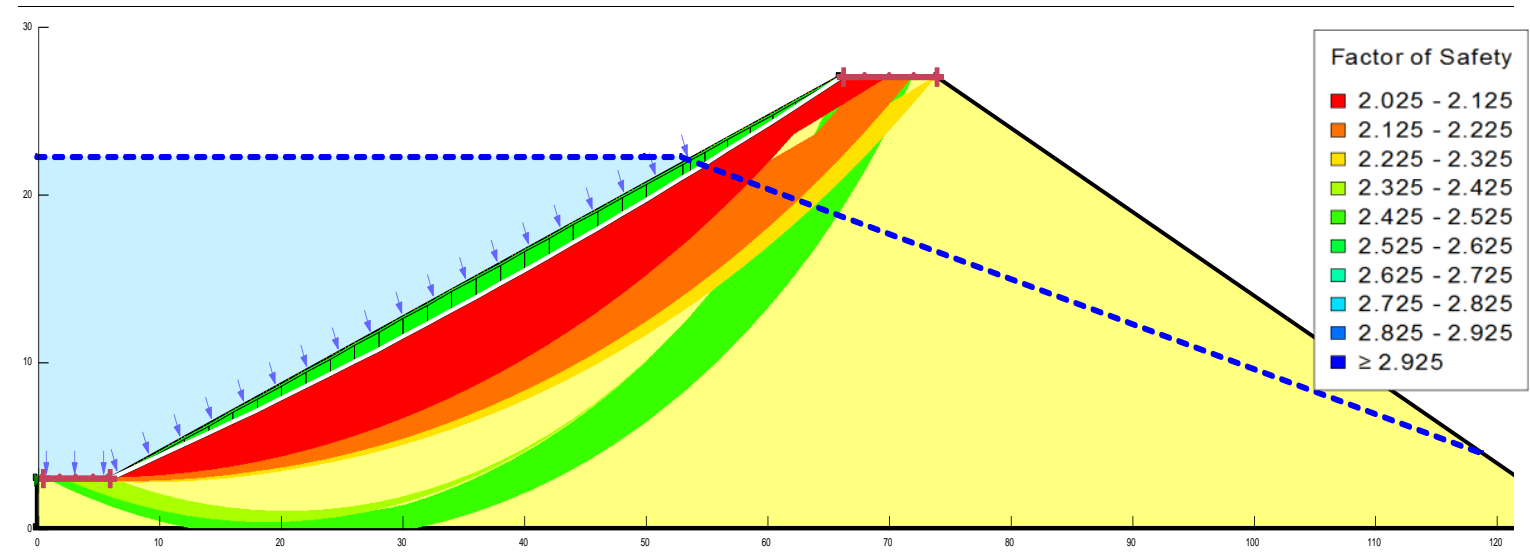

(e) $\mathrm{h}=0.8 \mathrm{H}$

Figure (6):Critical slip surface for Wand dam by Morgenstern-Price method (M1)

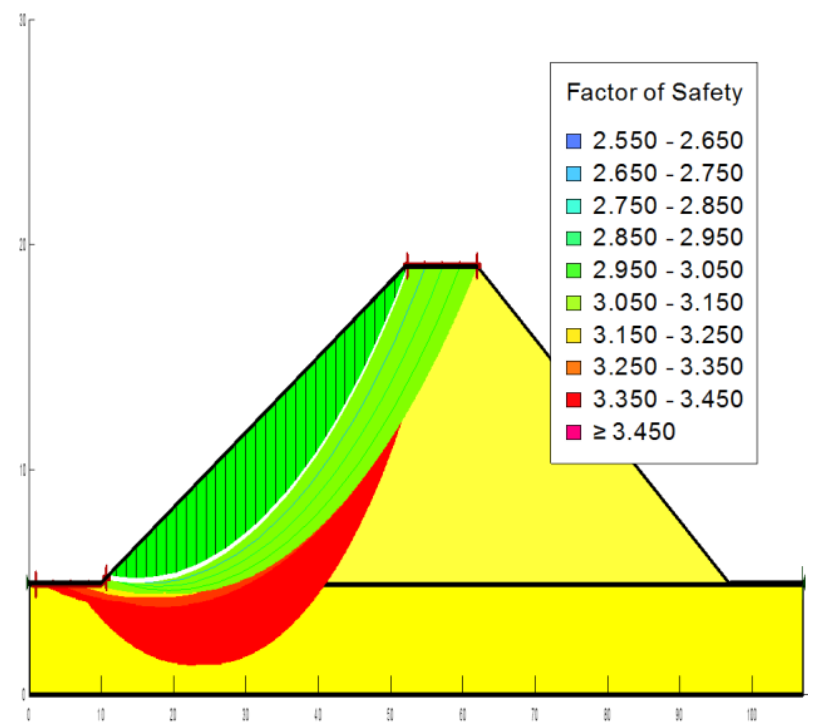

(a) $\mathrm{h}=0$

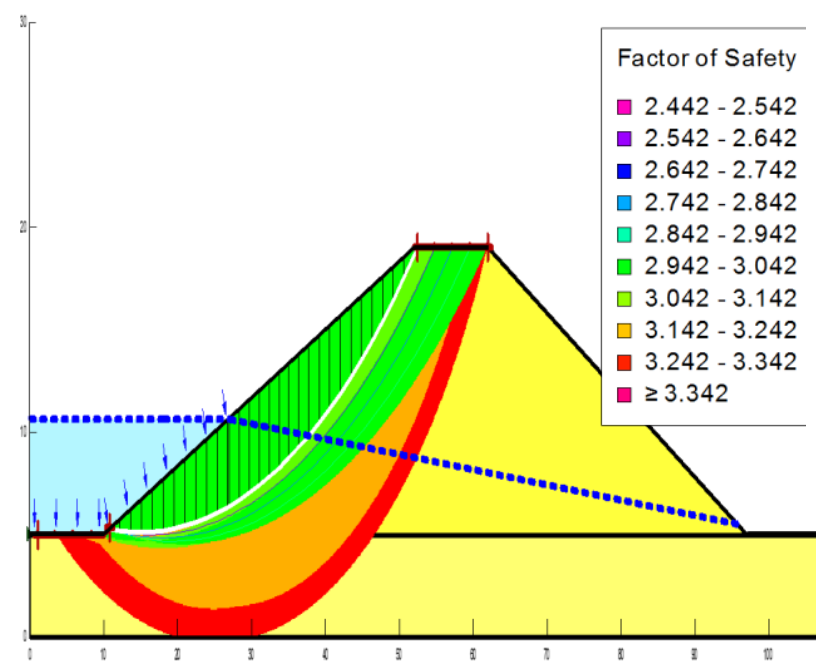

(c) $\mathrm{h}=0.4 \mathrm{H}$

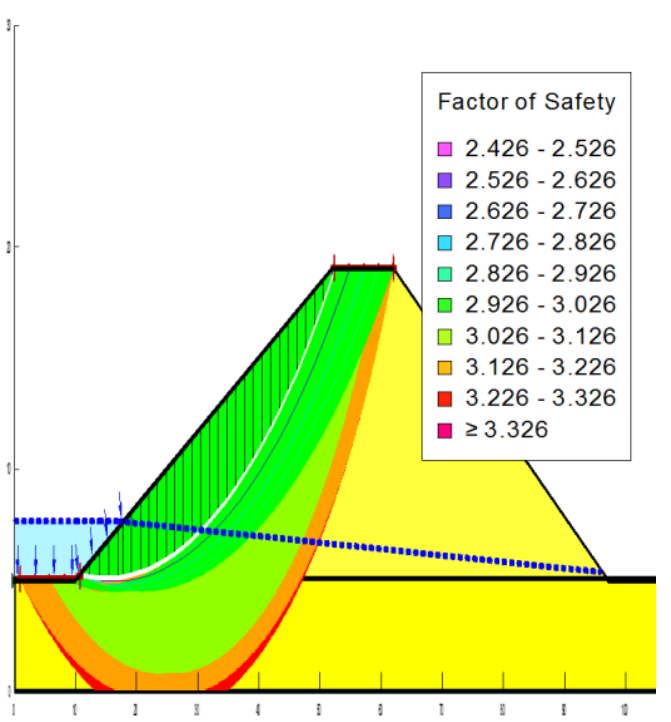

(b) $\mathrm{h}=0.2 \mathrm{H}$

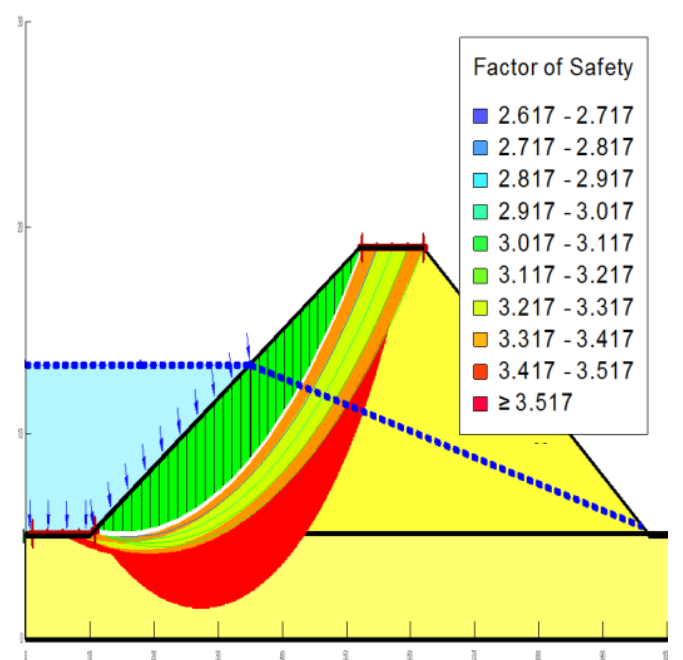

(d) $\mathrm{h}=0.6 \mathrm{H}$ 


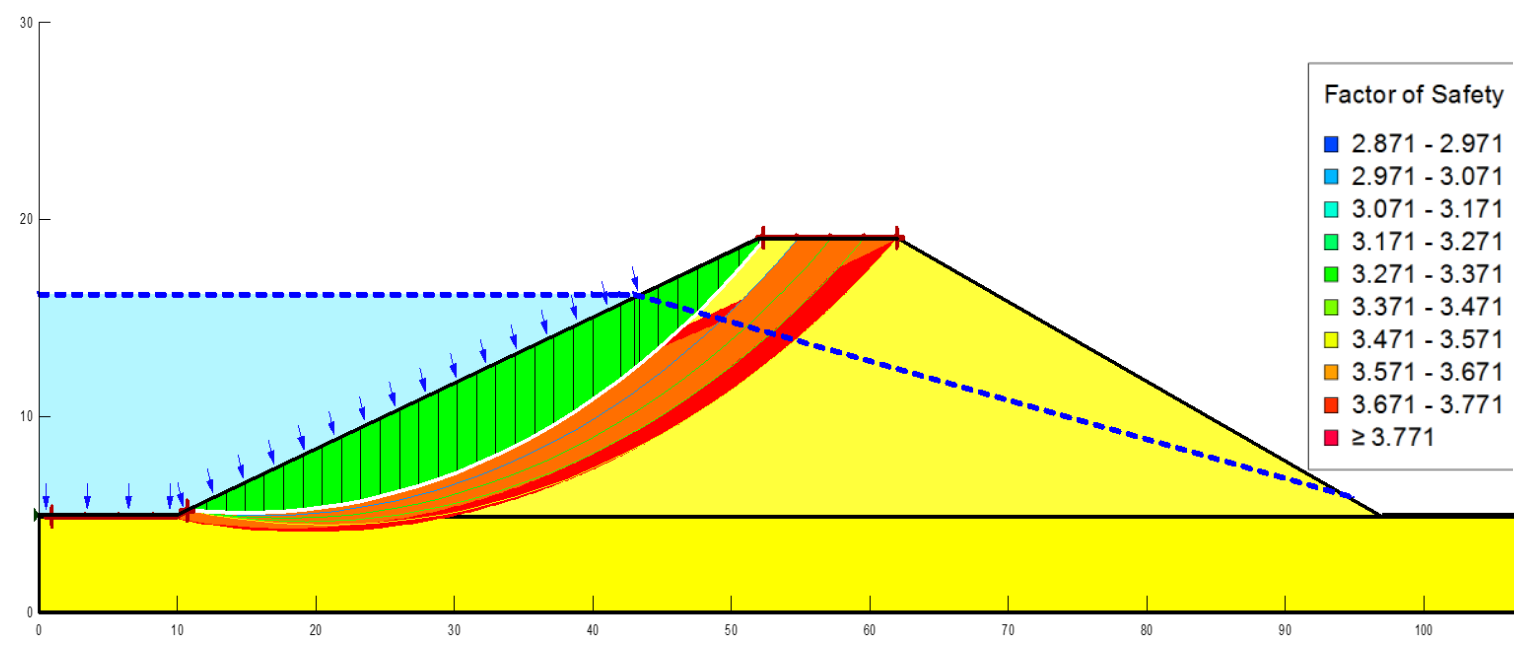

(e) $\mathrm{h}=0.8 \mathrm{H}$

Figure (7):Critical slip surface for Horan damH-2 by Morgenstern-Price method (M1)

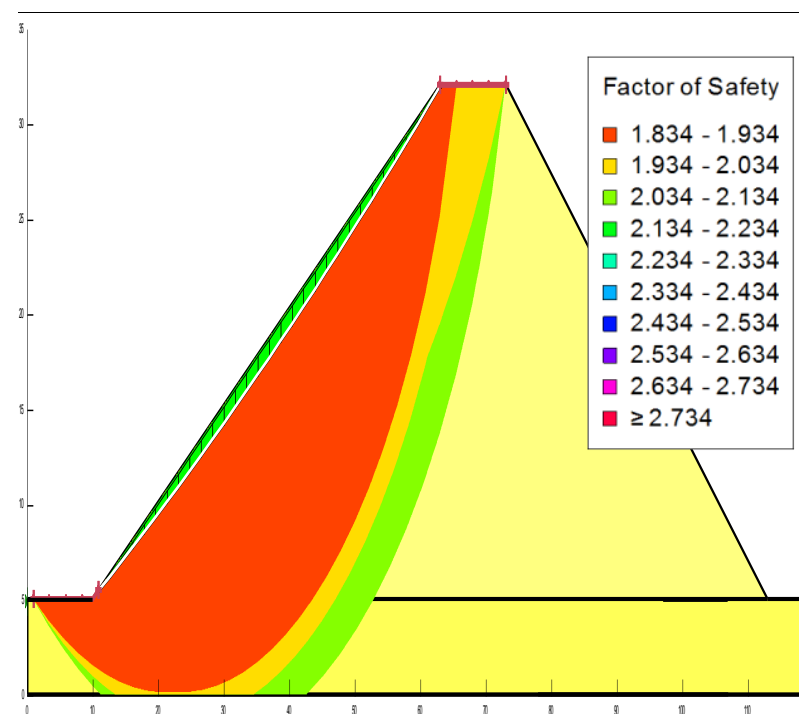

(a) $\mathrm{h}=0$

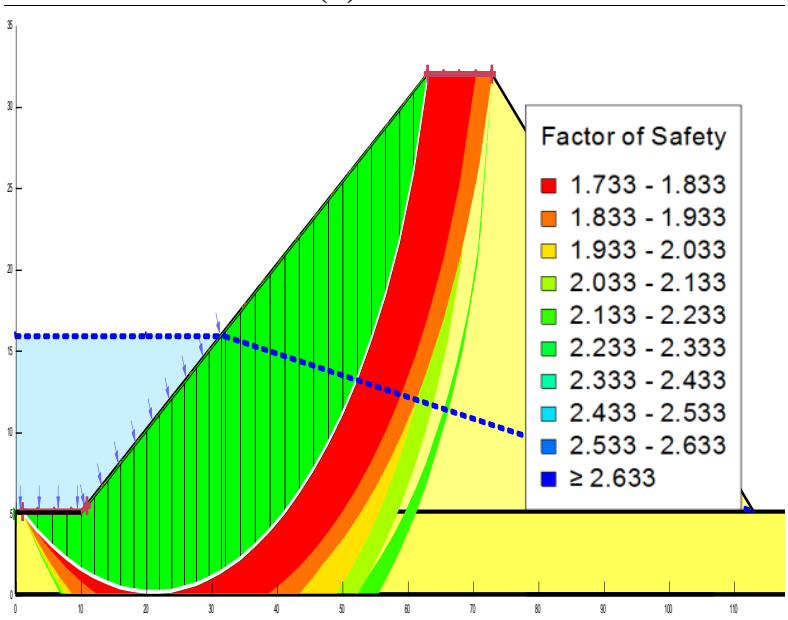

(c) $\mathrm{h}=0.4 \mathrm{H}$

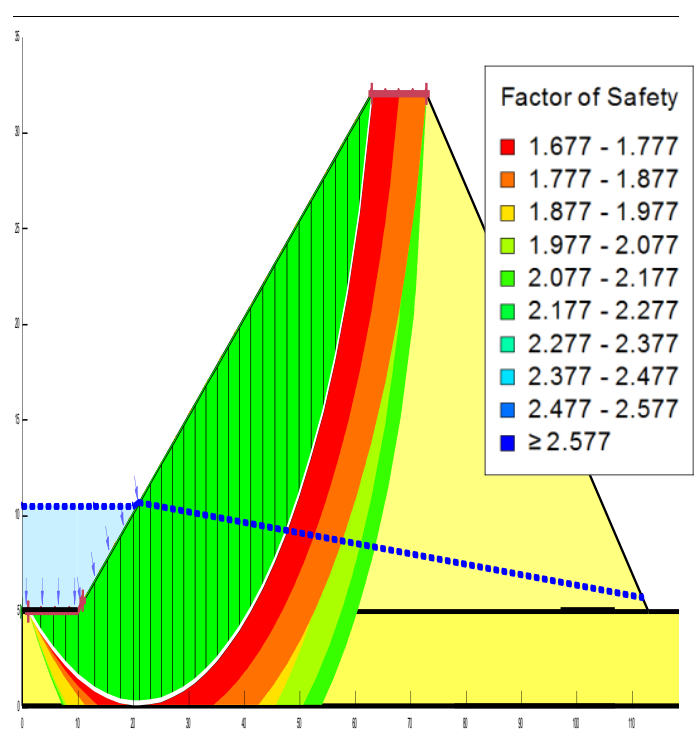

(b) $\mathrm{h}=0.2 \mathrm{H}$

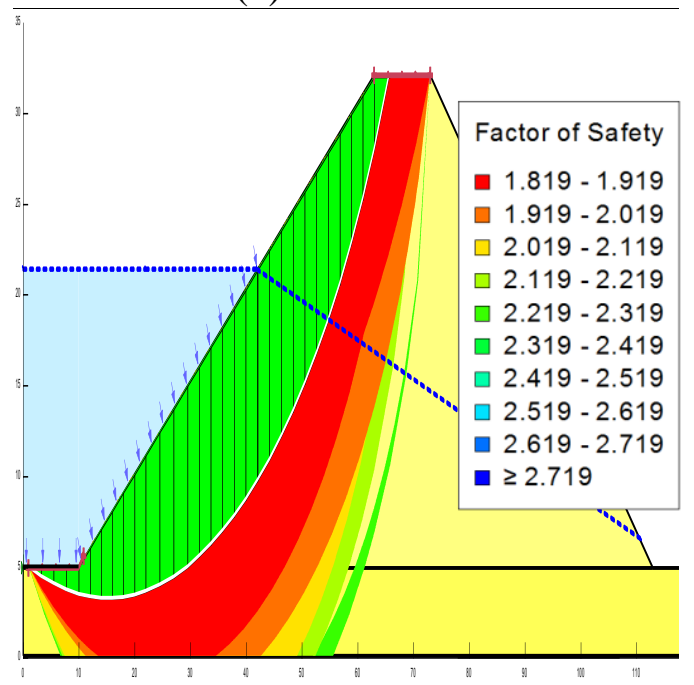

(d) $\mathrm{h}=0.6 \mathrm{H}$ 


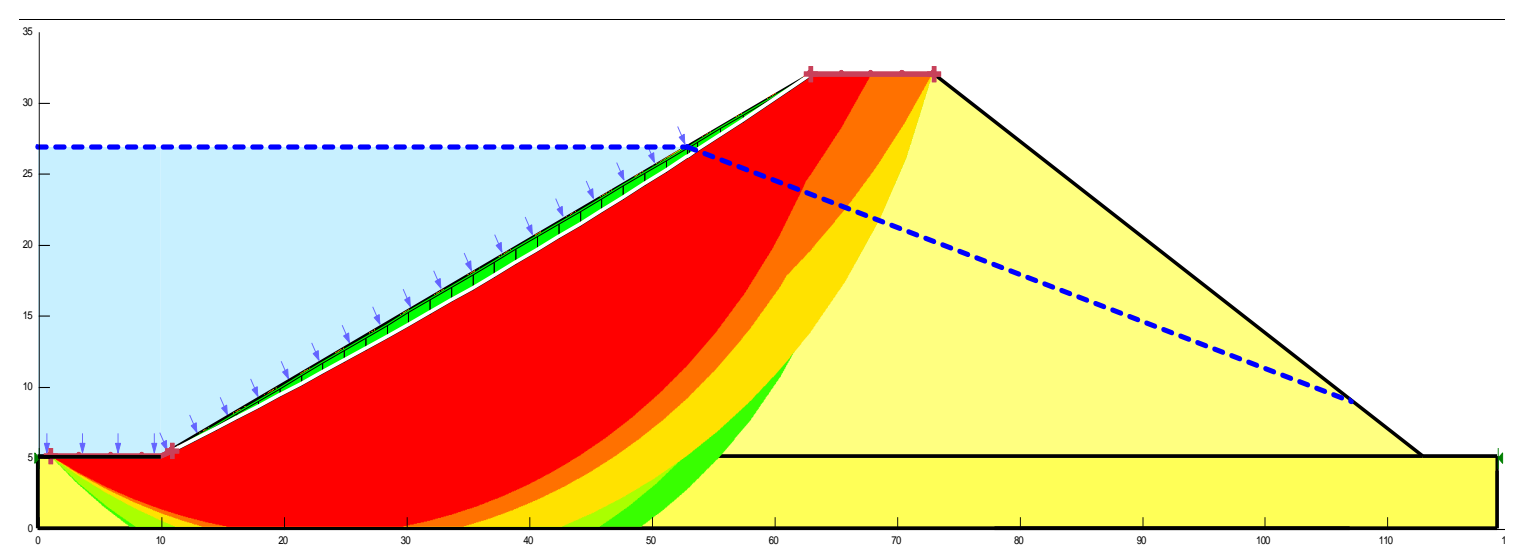

(e) $\mathrm{h}=0.8 \mathrm{H}$

Figure (8):Critical slip surface for Nian dam(1) by Morgenstern-Price method (M1)

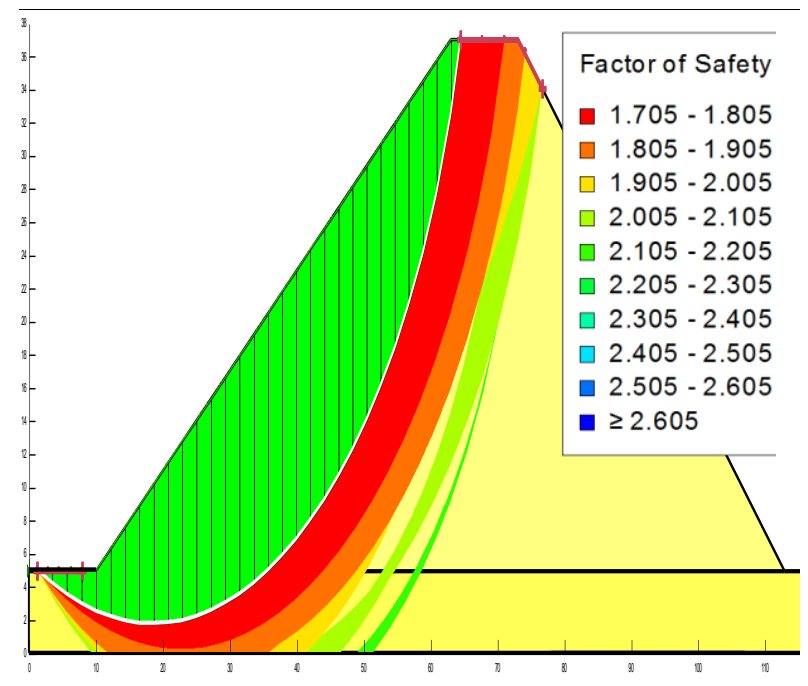

(a) $\mathrm{h}=0$

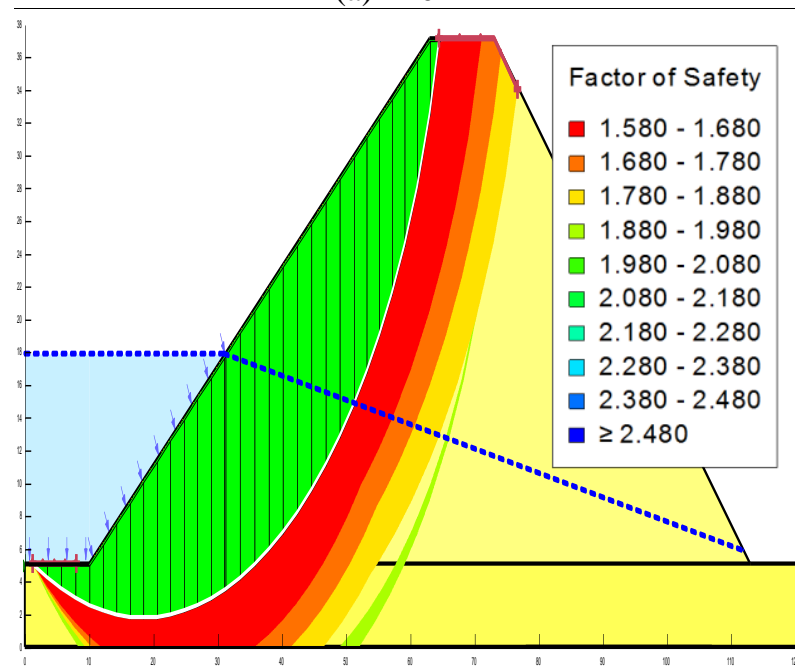

(c) $\mathrm{h}=0.4 \mathrm{H}$

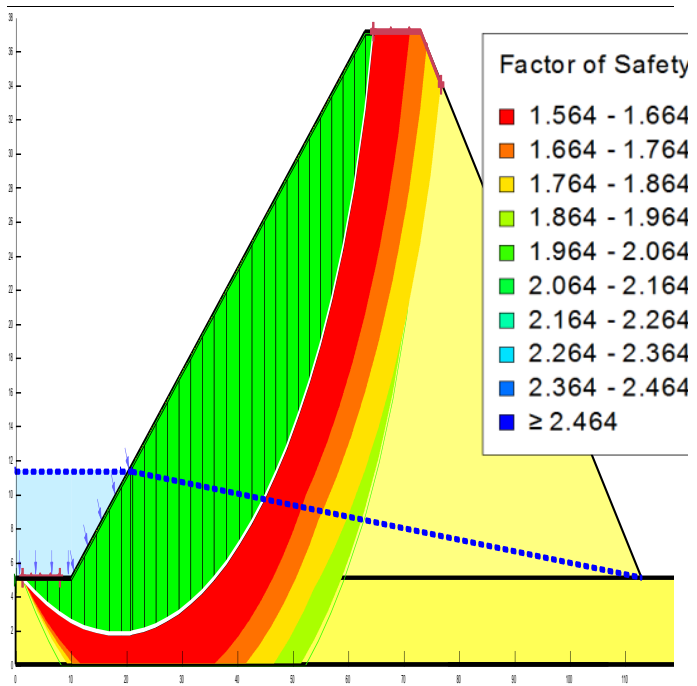

(b) $\mathrm{h}=0.2 \mathrm{H}$

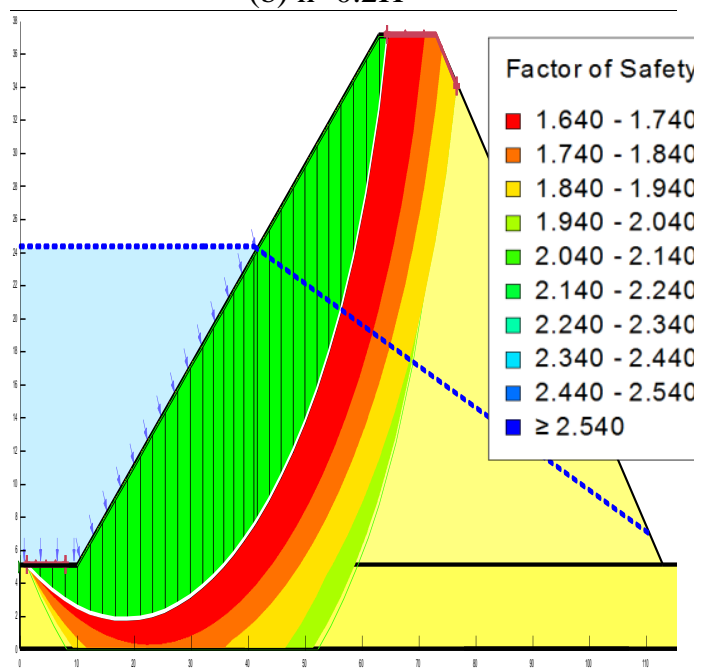

(d) $\mathrm{h}=0.6 \mathrm{H}$ 


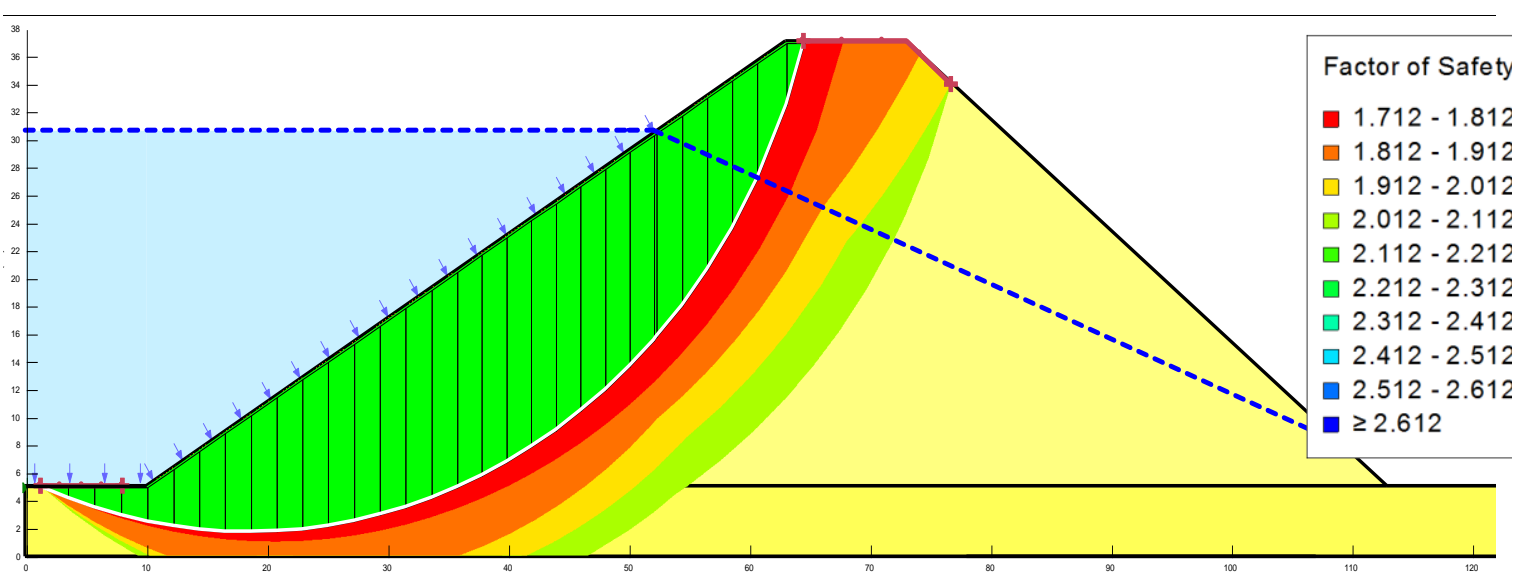

(e) $\mathrm{h}=0.8 \mathrm{H}$

Figure (9): Critical slip surface for Nian dam(2) by Morgenstern-Price method (M1)

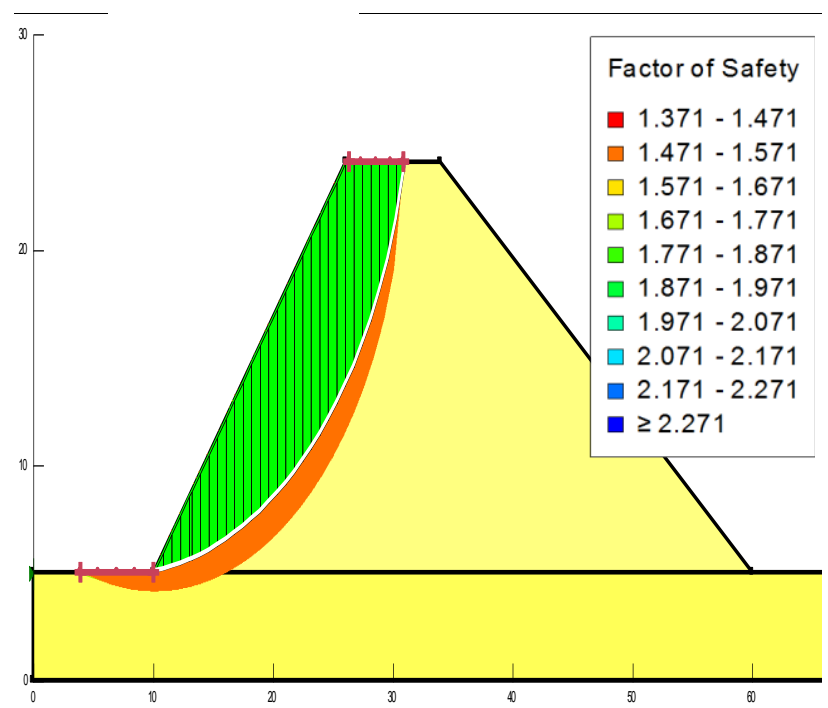

(a) $\mathrm{h}=0$

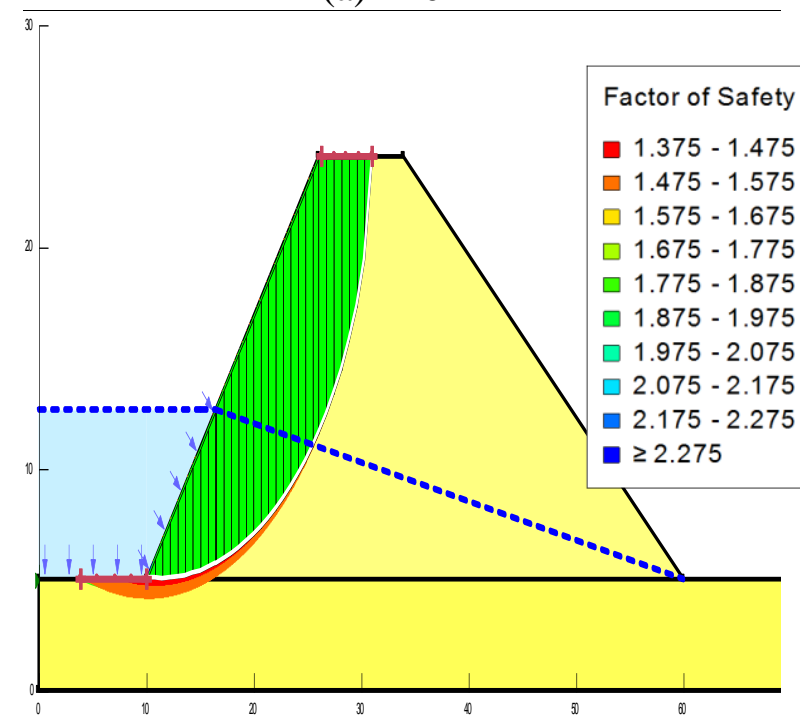

(c) $\mathrm{h}=0.4 \mathrm{H}$

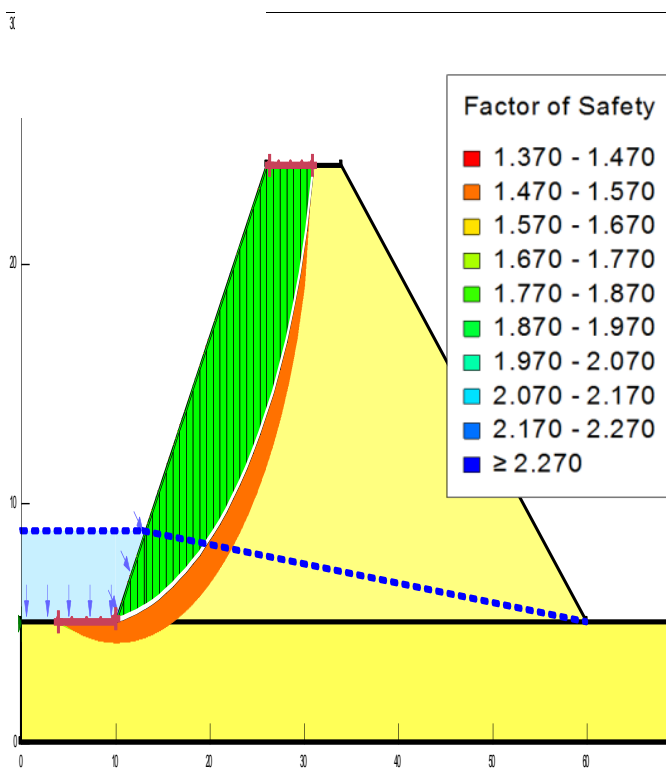

(b) $\mathrm{h}=0.2 \mathrm{H}$

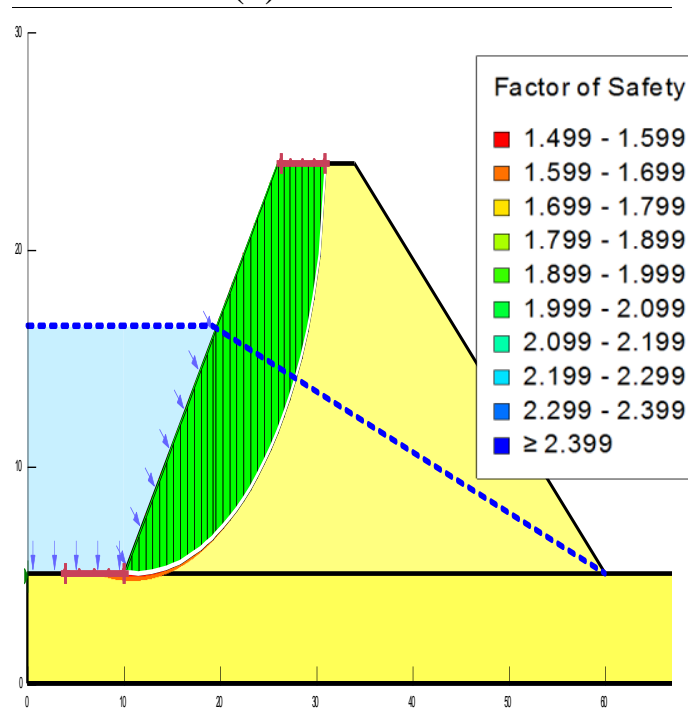

(d) $\mathrm{h}=0.6 \mathrm{H}$ 


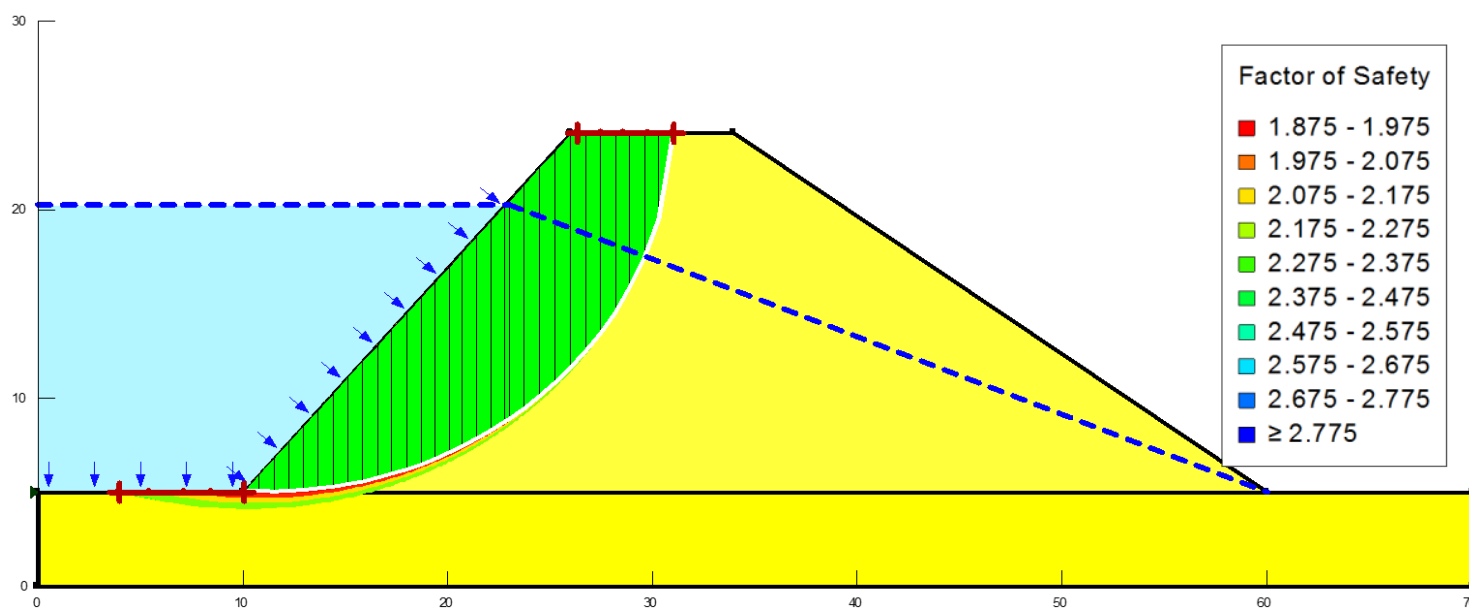

(e) $\mathrm{h}=0.8 \mathrm{H}$

Figure (10): Critical slip surface for Poomala dam by Morgenstern-Price method (M1)

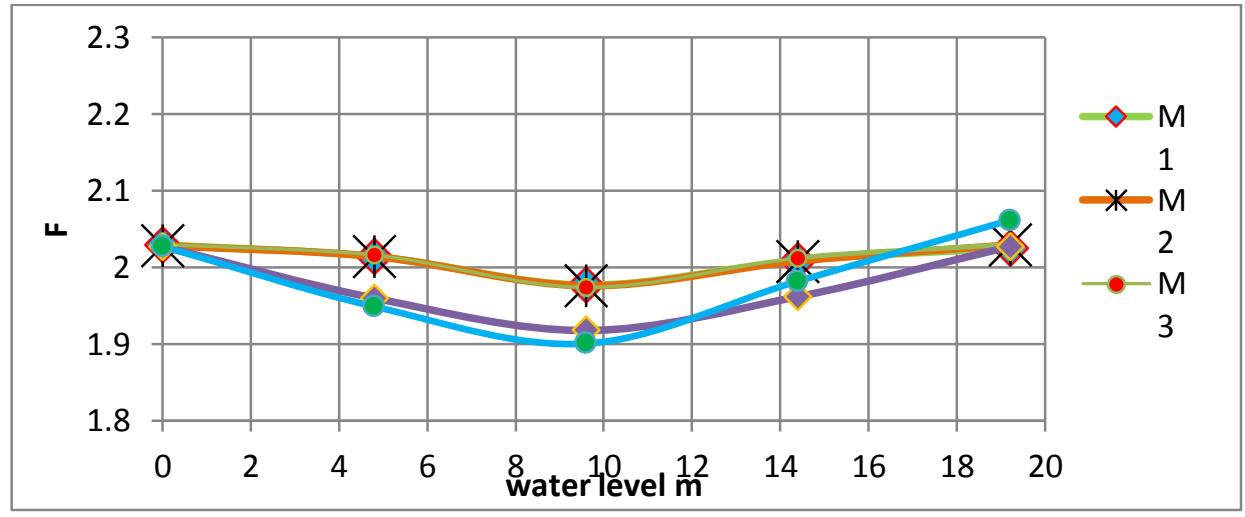

Figure (11): Relationship between minimum $(F) \&$ water level $(m)$ for Wand dam

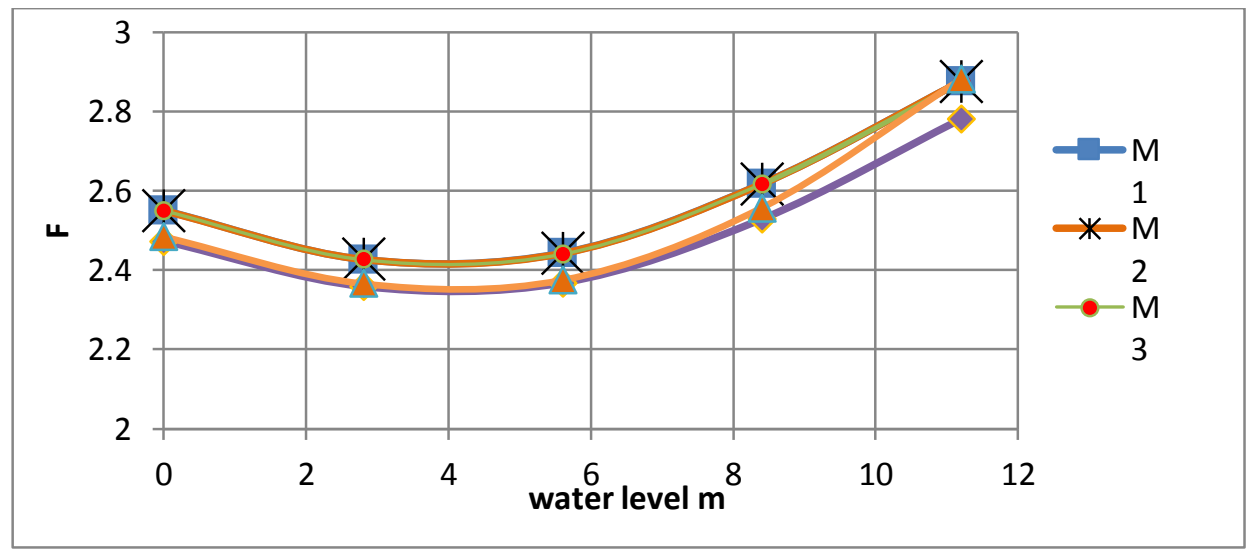

Figure (12): Relationship between minimum $(F) \&$ water level(m) for Horan dam H-2 


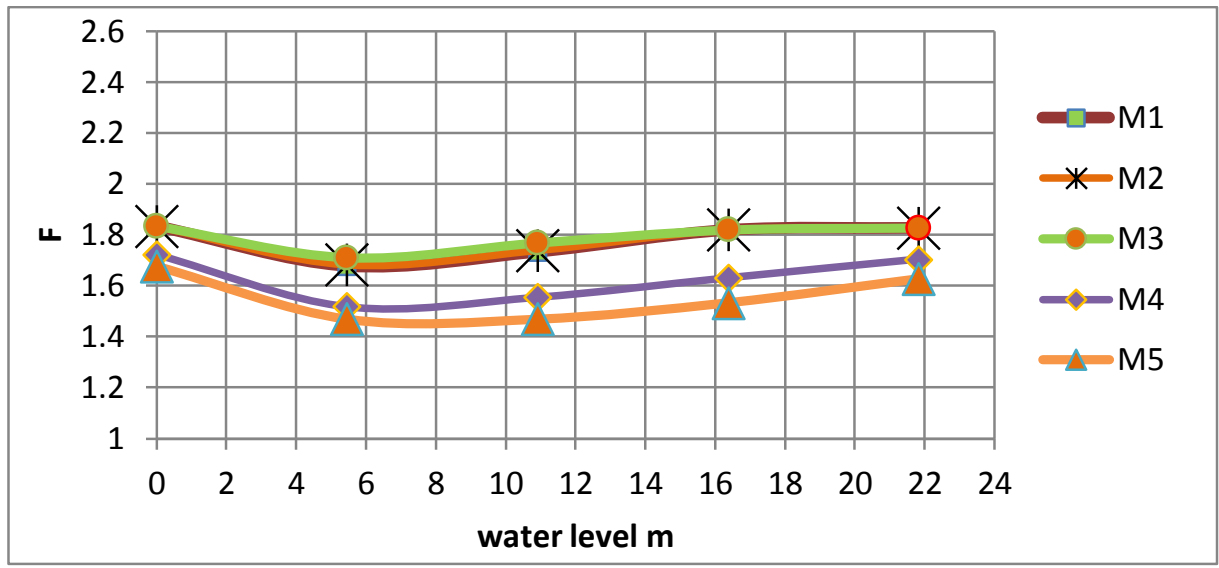

Figure (13): Relationship between minimum $(F) \&$ water level(m) for Nian dam(1)

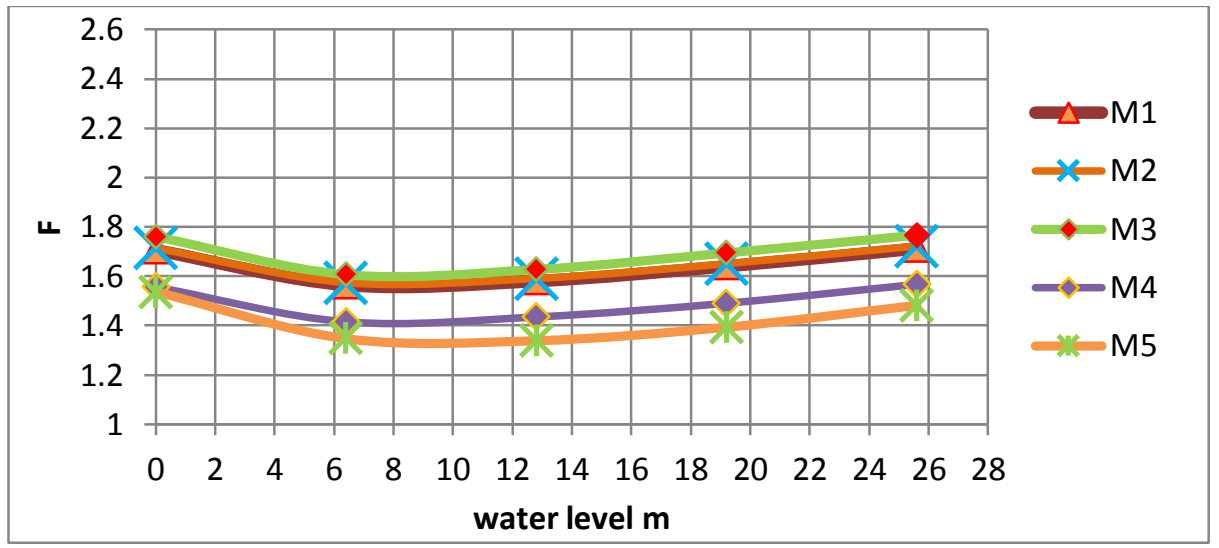

Figure (14): Relationship between minimum $(F) \&$ water level(m) for Nian dam(2)

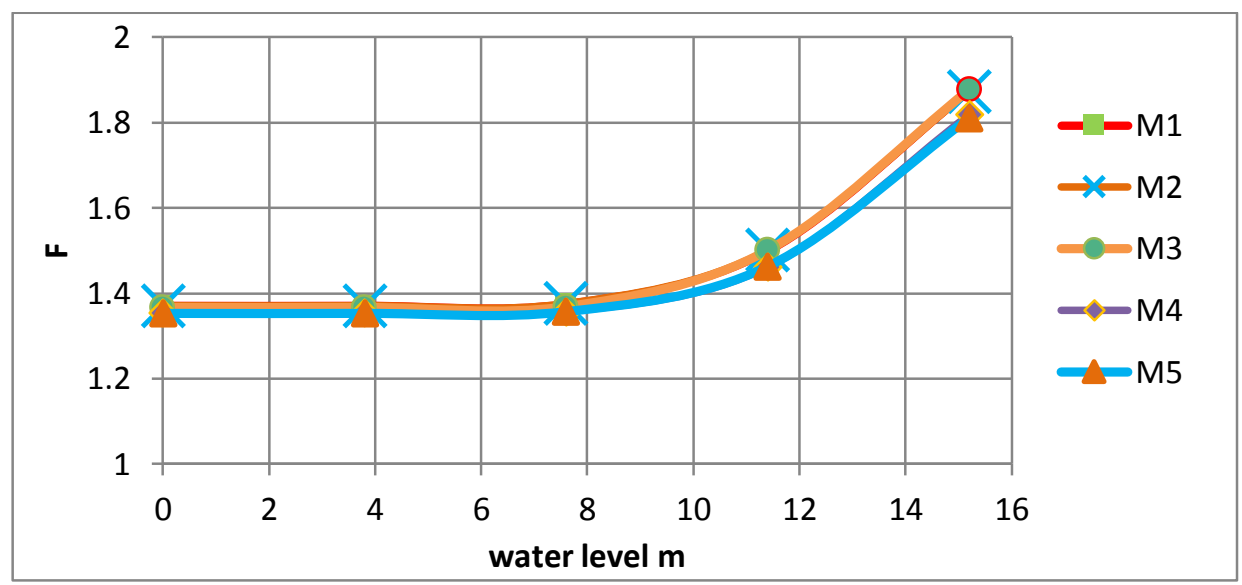

Figure (15): Relationship between minimum $(F) \&$ water level(m) for Poomala dam 